\title{
Inheritance of late flowering in natural variants of soybean cultivars under short-day conditions
}

\author{
Valeria Carpentieri-Pipolo(1), Leones Alves de Almeida(2), \\ Romeu Afonso de Souza Kiihl(2) and Eduardo Stefani Pagliosa ${ }^{(3)}$
}

\begin{abstract}
(1)Embrapa Trigo, Rodovia BR 285, Km 294, Caixa Postal 451, CEP 99001-970 Passo Fundo, RS, Brazil. E-mail: valeria.carpentieri-pipolo@embrapa.br (2)Tropical Melhoramento e Genética, Rodovia Celso Garcia Cid, Km 87, Caixa Postal 387, CEP 86181-000 Cambé, PR, Brazil. E-mail: leones@tmg.agr.br, romeukiihl@tmg.agr.br (3)Universidade Estadual de Londrina, Departamento de Agronomia, Caixa Postal 6001, CEP 86051-990 Londrina, PR, Brazil. E-mail: eduardopagliosa@gmail.com
\end{abstract}

\begin{abstract}
The objective of this work was to determine the inheritance of the long juvenile period trait in natural variants of the Doko, BR 9 (Savana), Davis, Embrapa 1 (IAS 5RC), and BR 16 soybean cultivars. Complete diallel crosses were made between the Doko and BR 16 cultivars and their variants. A 3:1 segregation ratio was observed in the $\mathrm{F}_{2}$ populations of the 'Doko' x Doko-18T, 'Doko' x Doko-Milionária, 'Davis' x São Carlos, and 'BR 9 (Savana)' x MABR92-836 (Savanão) crosses, indicating that the long juvenile period trait is controlled by a pair of recessive genes. The difference in late flowering between the Doko cultivar and both of its variants was caused by a recessive spontaneous mutation at the same genetic locus. However, the variants Doko-18T and Doko-Milionária are identical mutants that share a pair of genes that control the long juvenile period under short-day conditions. These mutants can be used in breeding programs to develop cultivars adapted to low-latitude tropical regions.

Index terms: Glycine max, breeding program, long juvenile period, low-latitude regions, natural mutation, photoperiod.

\section{Herança do florescimento tardio em variantes naturais de cultivares de soja em condições de dias curtos}

\begin{abstract}
Resumo - $\mathrm{O}$ objetivo deste trabalho foi determinar a herança do caráter período juvenil longo em variantes naturais das cultivares de soja Doko, BR 9 (Savana), Davis, Embrapa 1 (IAS 5RC) e BR 16. Foram realizados cruzamentos em dialelo completo entre as cultivares Doko e BR 16 e as suas variantes. Foi observada segregação 3:1 nas populações $\mathrm{F}_{2}$ dos cruzamentos 'Doko' x Doko-18T, 'Doko' x Doko-Milionária, 'Davis' x São Carlos e 'BR 9 (Savana)' x MABR92-836 (Savanão), o que indica que o caráter período juvenil longo é controlado por um par de genes recessivos. A diferença de florescimento tardio entre a cultivar Doko e ambas as suas variantes foi causada por uma mutação espontânea recessiva no mesmo loco genético. Entretanto, as variantes Doko-18T e Doko-Milionária são mutantes idênticos que compartilham um par de genes que controlam o período juvenil longo em condições de dia curto. Esses mutantes podem ser usados em programas de melhoramento para desenvolver cultivares adaptadas a regiões tropicais de baixa latitude.
\end{abstract}

Termos para indexação: Glycine max, programa de melhoramento, período juvenil longo, regiões de baixa latitude, mutação natural, fotoperíodo.

\section{Introduction}

Soybean [Glycine $\max$ (L.) Merr.] is a typical short-day plant, requiring short days for the induction of flowering; therefore, identifying genetic differences in flowering conditioned by photoperiod is necessary to modify flowering time and extend the soybean growing range (Watanabe et al., 2012).
Soybean is cultivated in a wide range of latitudes, from equatorial regions to high-latitude regions of up to 50 degrees of latitude. This wide adaptability is most likely associated with the genetic diversity of the plant (Liu et al., 2008, 2009).

Several natural mutations associated with late flowering under short-day conditions or long juvenile period traits (LJ) have been selected in soybean 
cultivars. These mutations may represent an important source of genes for the development of soybean cultivars adapted to different low-latitude regions or sowing periods in breeding programs (Thakare et al., 2010; Watanabe et al., 2012).

The genetic control of flowering time under short-day conditions is determined by a genetic system that is different and independent from the one that determines flowering under long-day conditions. Late flowering under short-day conditions is controlled by recessive alleles, whereas, under long-day conditions, it is dominant over early flowering (Liu et al., 2009; Watanabe et al., 2012).

The juvenile period in soybean grown under short-day conditions is a characteristic that directly affects plant height, number of nodes, maturing time, lowest pod insertion, leaf area, lodging degree, grain yield, and other important agronomic characteristics. Therefore, an understanding of the genetic control of this trait and the ability to perform efficient selection strategies are essential to produce new cultivars that are adapted to a larger variety of environments (Kong et al., 2010; Cober, 2011).

Carpentieri-Pípolo et al. (2002) studied the heritability of the long juvenile period in the MG/ BR 22 (Garimpo) soybean cultivar, supporting the development of cultivars adapted to short-day conditions. These authors observed that a single locus in recessive homozygosis does not produce the long juvenile period. The genes associated with the long juvenile period enable the plant to retain sufficient vegetative growth until flowering occurs under short-day conditions.

The objective of this work was to determine the inheritance of the long juvenile period trait in natural variants of the Doko, BR 9 (Savana), Davis, Embrapa 1 (IAS 5RC), and BR 16 soybean cultivars.

\section{Materials and Methods}

The inheritance study was performed with 12 genotypes (five cultivars and seven natural variants) and the $F_{1}$ and $F_{2}$ populations of the crosses between these genotypes (Table 1). Doko-18T and Doko-Milionária are natural variants of the Doko cultivar; MABR90-836 (Savanão) is the natural variant of the BR 9 (Savana) cultivar; São Carlos is the natural variant of the Davis cultivar; E93-96 is the natural variant of the Embrapa 1 (IAS 5RC) cultivar; and E92-7 and BR92-14638 are the natural variants of the BR 16 cultivar.

Since only one plant represented each variant, it had very similar characteristics to the genotype that gave rise to it, and the variants did not segregate in subsequent generations. The seven variant genotypes consisted of taller plants with later flowering and maturity than the original ones. Seeds were obtained from the germoplasm bank of Embrapa Soja, in the state of Paraná, Brazil.

Hybridizations and reciprocal crosses between original genotypes and variant genotypes were made for a total of 15 different hybrid combinations. The crosses were as follows: 'Doko' x Doko-18T, 'Doko' x Doko-Milionária, Doko-18T x Doko-Milionária, 'BR 9 (Savana)' x MABR90-836 (Savanão), 'Davis' x São Carlos, 'Embrapa 1 (IAS 5RC)' x E93-96 (Embrapa 1T), 'BR 16' x E92-7 (BR 16T-1), 'BR 16' x BR92-14638 (BR 16T-2), and E92-7 (BR 16T-1) x BR92-14638 (BR 16T-2).

Because the two mutations in the Doko cultivar were controlled by possibly identical recessive genes and, consequently, these mutations produced similar agronomic and morphologic phenotypes, an allelism test (Carpentieri-Pípolo et al., 2002) was performed with the Doko-18T x Doko-Milionária cross.

All crosses were made in greenhouse, and the advancement of the $F_{1}$ to the $F_{2}$ generation was performed. $F_{1}$ plants were grown in a greenhouse in the winter and were exposed to supplemental artificial light (incandescent and fluorescent) for additional 6 hours every day, during 20 days, to prevent early flowering. $F_{1}$ and $F_{2}$ populations were sown in the field on three sowing dates.

Field experiments were carried out in the municipality of Londrina, in the state of Paraná, southern Brazil $\left(23^{\circ} 11^{\prime} \mathrm{S}, 51^{\circ} 11^{\prime} \mathrm{W}\right.$, at an altitude of $620 \mathrm{~m}$ ). The climate of the region is classified as Cfa, humid subtropical, according to Köppen. The soil of the experimental site is classified as a Eutroferric Red Latosol. The soil was fertilized using the recommended application rate of $60 \mathrm{~kg} \mathrm{ha}^{-1}$ of $\mathrm{P}_{2} \mathrm{O}_{5}$ and $\mathrm{K}_{2} \mathrm{O}$.

$F_{1}$ and $F_{2}$ soybean populations were evaluated in two photoperiod treatments - short day (SD) under a 10 hour photoperiod and long day (LD) under a 12 hour photoperiod -, in three sowing dates: 
experiment I (SD), in the first week of October; experiment II (LD), in the last week of November; and experiment III (SD), in the last week of February. Experiment I (SD) was performed with 12 genotypes (five cultivars and seven variants) and the $F_{1}$ and $F_{2}$ populations of the crosses between these genotypes. Experiment II (LD) consisted of the Embrapa 1 (IAS 5RC) and BR 16 cultivars, their natural variants, and the $F_{1}$ and $F_{2}$ populations. Experiment III (SD) was performed with the Doko, BR 9 (Savana), and Davis cultivars, their variants, and the five $F_{1}$ and $\mathrm{F}_{2}$ populations obtained from the crosses with these genotypes. For each cross, approximately 60 parent plants, 40 reciprocal $F_{2}$ plants, $20 \mathrm{~F}_{1}$ plants, and $200 \mathrm{~F}_{2}$ plants were evaluated.

Sowing was done in a randomized complete block design in a split-plot arrangement with four replicates. The plots were comprised of eight subplots, four corresponding to the parents and the other four to the $\mathrm{F}_{2}$ generation (two rows were used for $\mathrm{F}_{2}$ plants and two rows for $F_{2}$ reciprocals). Each subplot consisted of $4.0 \times 0.5 \mathrm{~m}$ rows with seven plants per linear meter.
In all studied populations, date of flowering was determined as the first appearance of an open flower and was recorded for individual plants, every day.

In all experiments, plants were classified as early-flowering (CJ, conventional juvenile) or late-flowering (LJ, long conventional juvenile) by comparing the flowering date distribution of the respective early-flowering plants and the LJ parental lines. The data were categorized, and flowering categories were established using the narrow flowering range of the parents.

Data on days to flowering were grouped into two categories - early and late -, based on the mean, standard deviation, and range of the $F_{1}$ and $F_{2}$ populations of the parent plant. Frequency distribution curves of the $F_{2}$ population data were plotted to test genetic hypotheses conditioned on the expression of flowering.

A chi-square $\left(\chi^{2}\right)$ test for the distribution of days to flowering was used to test the genetic hypotheses of monogenic, digenic, and polygenic inheritance.

Table 1. Genotype pedigree of soybean (Glycine max) plants and information about their respective natural variants ${ }^{(1)}$.

\begin{tabular}{|c|c|}
\hline Genotype & Pedigree \\
\hline Doko & $\begin{array}{l}\text { Selection in the RB72-1 population (E70-46 / Viçoja; E70-47 / Viçoja; Hill / E70-47; E70-46 / Pickett; E70-47 / F65-1376; } \\
\text { and Davis / IAC 70-308). }\end{array}$ \\
\hline BR 16 & D69-B10-M58 / Davis \\
\hline BR 9 (Savana) & $\begin{array}{l}\text { Selection in the LoB74-2 population (Davis / IAC 73-481; Davis / IAC 73-1085; Davis / F67-5064; and Davis / Santa Rosa } \\
\text { atypical). }\end{array}$ \\
\hline Davis & D49-2573 / N45-1497 \\
\hline Embrapa 1 (IAS 5RC) & IAS 5(6) / Paranaíba \\
\hline Natural variants & Information \\
\hline Doko-18T & $\begin{array}{l}\text { Found in the fields of commercially produced Doko cultivars in the municipality of Lucas do Rio Verde, in the state of Mato } \\
\text { Grosso, Brazil, in 1982. When sown outside of the normal season, plant variants had approximately } 18 \text { trifoliate leaves, } \\
\text { whereas Doko had approximately } 13 \text {. }\end{array}$ \\
\hline Doko-Milionária & $\begin{array}{l}\text { Found in the fields of commercially produced Doko cultivars in the municipality of Sapezal, in the state of Mato Grosso, Brazil, } \\
\text { in 1990. This variant is a natural late-flowering mutant with a long juvenile period. }\end{array}$ \\
\hline E92-7 (BR 16T-1) & Found in multiplication fields of the BR 16 cultivar in the municipality of Toledo, in the state of Paraná, Brazil, in 1992. \\
\hline BR92-14638 (BR 16T-2) & Found in the fields of the BR 16 cultivar in the municipality of Londrina, in the state of Paraná, Brazil, in 1992. \\
\hline MABR90-836 (Savanão) & $\begin{array}{l}\text { Selected in a BR } 9 \text { (Savana) paddy in the municipality of Balsas, in the state of Maranhão, Brazil, in 1989. Compared to the } \\
\text { BR } 9 \text { cultivar, this variant had a significantly longer flowering period and achieved maturity later. }\end{array}$ \\
\hline São Carlos & $\begin{array}{l}\text { Found in the fields of commercially produced Davis cultivars in the municipality of São Carlos, in the state of São Paulo, } \\
\text { Brazil, in } 1980 .\end{array}$ \\
\hline E93-96 (Embrapa 1T) & $\begin{array}{l}\text { Found in the fields of commercially produced Embrapa } 1 \text { (IAS 5RC) cultivars in the municipality of Realeza, in the state of } \\
\text { Paraná, Brazil, in } 1992 .\end{array}$ \\
\hline
\end{tabular}

(1)Seeds were obtained in the germplasm bank of Embrapa Soja, in the state of Paraná, Brazil. 


\section{Results and Discussion}

No differences were observed in the segregation mode of populations derived from single and reciprocal crosses between the evaluated cultivars and their natural variants. This result suggests that under the experimental conditions there was no maternal effect on the genetic control of flowering. For this reason, data from single and reciprocal crosses were pooled to test the genetic hypothesis (Table 2).
A greater number of days to flowering was detected in the parents and in the $F_{1}$ and $F_{2}$ populations in experiment I, when compared to experiment III (Table 2). This result was attributed to the effect of seasonally mild temperatures that can delay flower induction. In contrast, plant populations sown in experiment III experienced early flowering, due to the increased night temperatures, which significantly affect the process of flower induction in the dark. The monthly mean air temperature from emergence to

Table 2. Means, standard deviation (SD), and range of days to flowering of parents $(\mathrm{P})$ and of $\mathrm{F}_{1}$ and $\mathrm{F}_{2}$ populations obtained from crosses between soybean (Glycine max) cultivars and their variants in three different experiments ${ }^{(1)}$.

\begin{tabular}{|c|c|c|c|c|c|c|c|}
\hline \multirow[t]{2}{*}{ Cross } & \multirow{2}{*}{$\begin{array}{l}\text { Parents and } \\
\text { generations }\end{array}$} & \multicolumn{2}{|c|}{ Experiment I } & \multicolumn{2}{|c|}{ Experiment II } & \multicolumn{2}{|c|}{ Experiment III } \\
\hline & & Mean \pm SD & Range & Mean \pm SD & Range & Mean \pm SD & Range \\
\hline \multirow{4}{*}{$\begin{array}{l}\text { 'Doko' x } \\
\text { Doko-18T }\end{array}$} & $\mathrm{P}_{1}$ & $85.26 \pm 3.36$ & $78-93$ & - & - & $62.78 \pm 2.37$ & $59-71$ \\
\hline & $\mathrm{P}_{2}$ & $100.34 \pm 2.33$ & $94-104$ & - & - & $88.26 \pm 4.36$ & 80-99 \\
\hline & $\mathrm{F}_{1}$ & $88.66 \pm 4.55$ & $78-96$ & - & - & $65.92 \pm 2.49$ & $62-72$ \\
\hline & $\mathrm{F}_{2}$ & $88.22 \pm 6.67$ & $75-107$ & - & - & $70.11 \pm 9.75$ & $58-102$ \\
\hline \multirow{4}{*}{$\begin{array}{l}\text { 'Doko' x } \\
\text { Doko-Milionária }\end{array}$} & $\mathrm{P}_{1}$ & $85.26 \pm 3.36$ & $78-93$ & - & - & $62.78 \pm 2.37$ & $59-71$ \\
\hline & $\mathrm{P}_{2}$ & $101.74 \pm 2.67$ & $96-106$ & - & - & $88.08 \pm 4.34$ & 80-98 \\
\hline & $\mathrm{F}_{1}$ & $85.58 \pm 3.98$ & 80-94 & - & - & $67.61 \pm 2.26$ & $62-72$ \\
\hline & $\mathrm{F}_{2}$ & $89.18 \pm 6.94$ & $75-108$ & - & - & $68.96 \pm 9.34$ & 58-98 \\
\hline \multirow{4}{*}{$\begin{array}{l}\text { Doko-18T x } \\
\text { Doko-Milionária }\end{array}$} & $\mathrm{P}_{1}$ & $100.34 \pm 2.33$ & $94-104$ & - & - & $88.26 \pm 4.36$ & $80-99$ \\
\hline & $\mathrm{P}_{2}$ & $101.74 \pm 2.67$ & $96-108$ & - & - & $88.08 \pm 4.34$ & 80-98 \\
\hline & $\mathrm{F}_{1}$ & $101.00 \pm 2.55$ & $96-105$ & - & - & $87.5 \pm 3.66$ & 83-94 \\
\hline & $\mathrm{F}_{2}$ & $100.01 \pm 3.25$ & 89-106 & - & - & $88.5 \pm 5.13$ & 79-103 \\
\hline \multirow{4}{*}{$\begin{array}{l}\text { 'BR } 9 \text { (Savana)' x } \\
\text { MABR90-836 (Savanão) }\end{array}$} & $\mathrm{P}_{1}$ & $62.76 \pm 1.54$ & $60-68$ & - & - & $52.4 \pm 1.32$ & $50-56$ \\
\hline & $\mathrm{P}_{2}$ & $100.08 \pm 2.87$ & $93-105$ & - & - & $79.48 \pm 2.67$ & $74-88$ \\
\hline & $\mathrm{F}_{1}$ & $73.50 \pm 4.40$ & $64-80$ & - & - & $61.33 \pm 3.33$ & $58-68$ \\
\hline & $\mathrm{F}_{2}$ & $76.69 \pm 10.82$ & $58-105$ & - & - & $61.36 \pm 8.30$ & $50-85$ \\
\hline \multirow{4}{*}{$\begin{array}{l}\text { 'Davis' x } \\
\text { São Carlos }\end{array}$} & $\mathrm{P}_{1}$ & $39.10 \pm 2.44$ & $33-44$ & - & - & $37.00 \pm 2.29$ & $34-43$ \\
\hline & $\mathrm{P}_{2}$ & $56.78 \pm 2.17$ & $53-61$ & - & - & $53.96 \pm 1.96$ & $51-58$ \\
\hline & $\mathrm{F}_{1}$ & $42.39 \pm 2.29$ & $37-47$ & - & - & $42.70 \pm 4.66$ & $36-49$ \\
\hline & $\mathrm{F}_{2}$ & $47.33 \pm 5.93$ & $34-62$ & - & - & $45.93 \pm 6.28$ & $34-58$ \\
\hline \multirow{4}{*}{$\begin{array}{l}\text { 'Embrapa } 1 \text { (IAS 5RC)' x } \\
\text { E93-96 }\end{array}$} & $\mathrm{P}_{1}$ & $42.74 \pm 1.17$ & $41-46$ & $41.56 \pm 1.32$ & $40-44$ & - & - \\
\hline & $\mathrm{P}_{2}$ & $45.24 \pm 1.49$ & $43-49$ & $44.30 \pm 2.47$ & $40-50$ & - & - \\
\hline & $\mathrm{F}_{1}$ & $42.75 \pm 0.14$ & $42-46$ & $42.40 \pm 3.28$ & $40-48$ & - & - \\
\hline & $\mathrm{F}_{2}$ & $45.32 \pm 2.13$ & $41-52$ & $44.16 \pm 2.52$ & 39-53 & - & - \\
\hline \multirow{4}{*}{$\begin{array}{l}\text { 'BR } 16 ' x \\
\text { E92-7 }\end{array}$} & $\mathrm{P}_{1}$ & $35.36 \pm 1.73$ & $33-39$ & $41.88 \pm 1.04$ & $40-44$ & - & - \\
\hline & $\mathrm{P}_{2}$ & $45.72 \pm 1.24$ & $44-49$ & $44.84 \pm 1.60$ & $41-48$ & - & - \\
\hline & $\mathrm{F}_{1}$ & $41.07 \pm 2.59$ & $38-48$ & $42.00 \pm 0.75$ & $41-43$ & - & - \\
\hline & $\mathrm{F}_{2}$ & $40.46 \pm 3.64$ & $33-49$ & $42.90 \pm 2.87$ & $39-56$ & - & - \\
\hline \multirow{4}{*}{$\begin{array}{l}\text { 'BR 16' x } \\
\text { E92-14638 }\end{array}$} & $\mathrm{P}_{1}$ & $35.36 \pm 1.73$ & $33-39$ & $41.99 \pm 1.04$ & $40-44$ & - & - \\
\hline & $\mathrm{P}_{2}$ & $60.08 \pm 1.95$ & $56-66$ & $57.04 \pm 1.73$ & $55-61$ & - & - \\
\hline & $\mathrm{F}_{1}$ & $40.85 \pm 3.30$ & $32-46$ & $41.85 \pm 2.77$ & $38-46$ & - & - \\
\hline & $\mathrm{F}_{2}$ & $40.62 \pm 6.58$ & $33-66$ & $43.08 \pm 5.11$ & $37-60$ & - & - \\
\hline \multirow{4}{*}{$\begin{array}{l}\text { E92-7 x } \\
\text { BR92-14638 }\end{array}$} & $\mathrm{P}_{1}$ & $45.72 \pm 1.24$ & $44-49$ & $44.84 \pm 1.60$ & $41-48$ & - & - \\
\hline & $\mathrm{P}_{2}$ & $60.08 \pm 1.95$ & $56-66$ & $57.04 \pm 1.73$ & $55-61$ & - & - \\
\hline & $\mathrm{F}_{1}$ & $46.96 \pm 1.45$ & $45-52$ & $47.72 \pm 2.35$ & $44-55$ & - & - \\
\hline & $\mathrm{F}_{2}$ & $49.73 \pm 7.80$ & $39-68$ & $47.25 \pm 6.14$ & $37-62$ & - & - \\
\hline
\end{tabular}

${ }^{(1)}$ Experiment I, short day, first week of October; Experiment II, long day, last week of November; and Experiment III, short day, last week of February. 
flowering was: $23.3^{\circ} \mathrm{C}$ for experiment I, with maximum of $34^{\circ} \mathrm{C}$ and minimum of $18.8^{\circ} \mathrm{C} ; 24.2^{\circ} \mathrm{C}$ for experiment II, with maximum of $31.1^{\circ} \mathrm{C}$ and minimum of $12.8^{\circ} \mathrm{C}$; and $23.7^{\circ} \mathrm{C}$ for experiment III, with maximum of $33.2^{\circ} \mathrm{C}$ and minimum of $15^{\circ} \mathrm{C}$. Under the conditions of short photoperiod and warm temperature, all lines flowered approximately at the same time. However, cooler temperatures under a 20 hour photoperiod led to delayed flowering (Cober, 2011). Liu et al. (2011) reported that in a tropical location, such as Thailand, planting starts in November because flowering time is affected by warmer temperature rather than by the photoperiod; therefore, the high temperature during the night has a more significant effect on the induction of flowering.

The 'Doko' x Doko-18T cross showed a bimodal distribution of the $\mathrm{F}_{2}$ plants, with greater concentrations of early-flowering plants (Table 3). The distribution of the $F_{1}$ plants was similar to and in the same range of variation as that of the Doko cultivar, indicating that the early-flowering trait is dominant. In the $\mathrm{F}_{2}$ population, ratios of 206:65 and 234:78 of early to late plants were observed in experiments I and III, respectively. The $\chi^{2}$ values were strongly significant $(\mathrm{p}>0.99)$, indicating a discrepancy between the expected genotypic ratio of 3:1 and the observed ratios. As a result, the hypothesis of independent segregation was rejected. The patterns of segregation indicated that the LJ trait was controlled by recessive alleles at two independent loci exhibiting epistasis. Similar results were found by Carpentieri-Pípolo et al. $(2000,2002)$ for the 'Paraná' $\mathrm{x}$ 'Bossier' cross.

The frequency distributions of $F_{2}$ plants from the 'Doko' x Doko-Milionária cross showed a segregation pattern similar to that of the 'Doko' $\mathrm{x}$ Doko-18T cross. Segregation ratios of 189:60 and 256:66 were obtained in experiments I and III, respectively. These frequencies were similar to the expected $3: 1$ genotypic ratio, as shown by the $\chi^{2}$ value $(0.1084, \mathrm{p}=0.70-0.50)$ and probability value $(34.842, \mathrm{p}=0.10-0.05)$. This result is an indicative that the late flowering of the Doko-Milionária variant is controlled by a recessive gene at a single locus. Cober (2011) observed

Table 3. Chi-square test $\left(\chi^{2}\right)$ and observed and expected probability of having the trait associated with days to flowering in $\mathrm{F}_{2}$ populations from nine crosses between soybean (Glycine max) cultivars and their variants for three sowing dates ${ }^{(1)}$.

\begin{tabular}{|c|c|c|c|c|c|c|c|c|c|c|c|}
\hline \multirow[t]{2}{*}{$\overline{\text { Cross }}$} & \multirow[t]{2}{*}{ Experiment $^{(2)}$} & \multirow[t]{2}{*}{ № } & \multicolumn{2}{|c|}{ CJ } & \multicolumn{2}{|c|}{ LJ } & \multirow[t]{2}{*}{ Ratio } & \multirow[t]{2}{*}{$\chi^{2}$} & \multicolumn{3}{|c|}{ Probability } \\
\hline & & & Obs. & Exp. & Obs. & Exp. & & & & & \\
\hline \multirow{2}{*}{ 'Doko' x Doko-18T } & I & 271 & 206 & $(203.25)$ & 65 & $(67.75)$ & 03:01 & 0.1488 & 0.70 & & 0.50 \\
\hline & III & 312 & 234 & $(234.00)$ & 78 & $(78.00)$ & 03:01 & 0.0000 & & $>$ & 0.99 \\
\hline \multirow{2}{*}{ 'Doko' x Doko-Milionária } & I & 249 & 189 & $(186.75)$ & 60 & $(62.25)$ & 03:01 & 0.1084 & 0.70 & & 0.50 \\
\hline & III & 322 & 256 & $(241.50)$ & 66 & $(80.50)$ & 03:01 & 34.842 & 0.10 & & 0.05 \\
\hline \multirow{2}{*}{ Doko-18T x Doko-Milionária } & $\mathrm{I}$ & 193 & - & - & 193 & - & - & - & - & & - \\
\hline & III & 209 & - & - & 209 & - & - & - & - & & - \\
\hline \multirow{2}{*}{ 'BR 9 (Savana)' x MABR90-836 (Savanão) } & I & 247 & 181 & $(185.25)$ & 66 & $(61.75)$ & 03:01 & 0.3900 & 0.70 & & 0.50 \\
\hline & III & 272 & 217 & $(204.00)$ & 55 & $(68.00)$ & 03:01 & 33.137 & 0.10 & & 0.05 \\
\hline \multirow{2}{*}{ 'Davis' x São Carlos } & I & 336 & 250 & $(252.00)$ & 86 & $(84.00)$ & 03:01 & 0.0635 & 0.80 & & 0.70 \\
\hline & III & 277 & 167 & $(177.75)$ & 70 & $(59.25)$ & 03:01 & 26.005 & 0.20 & & 0.10 \\
\hline \multirow{2}{*}{ 'Embrapa 1 (IAS 5RC)' x E93-96 } & I & 341 & - & - & - & - & - & - & - & & - \\
\hline & II & 277 & - & - & - & - & - & - & - & & - \\
\hline \multirow{2}{*}{ 'BR 16' x E92-7 } & I & 338 & 261 & $(253.50)$ & 77 & $(84.50)$ & 03:01 & 0.8876 & 0.50 & & 0.30 \\
\hline & II & 296 & - & - & - & - & - & - & - & & - \\
\hline \multirow{2}{*}{ 'BR 16' x BR92-14638 } & I & 267 & 246 & $(250.31)$ & 21 & (16.69) & $15: 01$ & 11.887 & 0.30 & & 0.20 \\
\hline & II & 247 & 227 & $(231.56)$ & 20 & (15.44) & $15: 01$ & 14.383 & 0.30 & & 0.20 \\
\hline \multirow{2}{*}{ E92-7 x BR92-14638 } & I & 272 & 202 & $(204.00)$ & 70 & $(68.00)$ & 03:01 & 0.0784 & 0.80 & & 0.70 \\
\hline & II & 212 & 166 & $(159.00)$ & 46 & $(53.00)$ & 03:01 & 12.327 & 0.30 & & 0.20 \\
\hline
\end{tabular}

${ }^{(1)} \mathrm{No}$, total number of individuals; CJ, conventional-juvenile flowering type; LJ, long-juvenile flowering type; Obs., observed phenotypic ratio; Exp., expected phenotypic ratio. ${ }^{(2)}$ Experiment I, short day, first week of October; Experiment II, long day, last week of November; and Experiment III, short day, last week of February. 
flowering responses of the Paraná cultivar and its isoline Paranagoiana under very short photoperiods. The juvenile period of Paranagoiana is five days longer than that of 'Paraná' and is controlled by a recessive gene in a single locus (e6e6).

No evidence of segregation was found by the allelism test in the Doko-18T x Doko-Milionária cross; therefore, it was not possible to classify the $F_{2}$ plants as early- or late-flowering. Because of the great similarities in the unimodal distribution of the $F_{2}$ plants and in the behavior of the $\mathrm{F}_{1}$ plants of the two 'Doko' mutants, the late flowering observed in both mutants was believed to be controlled by identical recessive alleles originating from spontaneous mutations at the same locus.

The segregation of $F_{2}$ plants from the 'BR 9 (Savana)' x MABR90-836 (Savanão) cross followed a bimodal distribution, with an increased frequency of early-flowering plants. However, although the $F_{1}$ plants were more frequently found in the range of earlier-flowering parents, they were not found throughout the entire range of variation of the parents. Because $F_{1}$ plants flower later than 'BR 9 (Savana)' plants and because $\mathrm{F}_{2}$ plants with flowering amplitude equal to or lower than that of the $F_{1}$ generation occurred at a higher frequency, the earliness trait may be partially dominant.

After the $F_{2}$ plants were categorized, ratios of 181:66 and 217:55 were observed for experiments I and II, respectively. These proportions were consistent with the expected 3:1 genotypic ratio, with $\chi^{2}$ and probability values of $0.3900 \quad(\mathrm{p}=0.70-0.50)$ and 33.137 ( $\mathrm{p}=0.10-0.05)$, respectively; this indicates that flowering in this cross is characterized by monogenic inheritance and that early flowering is partially dominant. The mutation that controls late flowering in the MABR90-836 (Savanão) genotype is recessive.

The $F_{1}$ population of the 'Davis' x São Carlos cross was characterized by an average flowering time of approximately 40 days in both experiments, with a range of variation only slightly larger than that of 'Davis' and consistently smaller than that of São Carlos (Table 2). This may indicate that early flowering is partially dominant. The segregation in experiment I followed a bimodal distribution, with the greatest concentration of plants in the range of variation of the earlier-flowering parents and the $F_{1}$ plants. In experiment III, even though the distribution was not clearly bimodal, all $\mathrm{F}_{2}$ plants in the flowering range of $F_{1}$ plants could be considered as belonging to the early-flowering class. The proportions of 250:86 and 167:70 observed in experiments I and III, respectively, were consistent with the expected monogenic ratio of $3: 1$, with $\chi^{2}$ values of $0.0635(p=0.80-0.70)$ and 26.005 $(\mathrm{p}=0.20-0.10)$ (Table 3$)$. These results suggest that the difference in days to flowering between São Carlos and 'Davis' depended mainly on genetic differences instead of on environmental errors (Thakare et al., 2010); in addition, the genetic rates indicate that the São Carlos variant most likely differs from the Davis cultivar by one mutation in a pair of recessive alleles and in one gene locus.

The days to flowering in experiments I and II for the Embrapa 1 (IAS 5RC) and E93-96 parents and the $\mathrm{F}_{1}$ and $\mathrm{F}_{2}$ populations did not differ significantly. Because the difference in time to flowering between the parents was small, the segregation followed a unimodal distribution; therefore, it was not possible to categorize the segregation in this cross into well-defined flowering classes.

Flowering did not differ significantly, in experiments I and II, for the BR 16 cultivar and its variants - E92-7 and BR92-14638. However, the BR 16 cultivar responded positively, flowering approximately six days later in experiment II (SD). The differences between the parents were most marked in experiment I. In this experiment, the flowering of E92-7 and BR92-14638 occurred 10 and 25 days later than that of the BR 16 cultivar, respectively. Segregation in the $F_{2}$ population of the 'BR 16' x E92-7 cross did not show a typical bimodal distribution, probably because of the small difference in time to flowering between these parents. However, the existence of genetic dominance controlling early flowering was evident. The monogenic inheritance hypothesis can be considered only in the segregation of experiment I; indeed, in experiment II, the time to flowering of the E92-7 variant was similar to that of 'BR 16', and the segregation of the cross of these two variants produced no well-defined flowering classes, although transgressive variation towards later flowering was observed in the BR 16 genotype. Using the categorization criteria for the segregation of experiment $I$ in the analysis of the daily distribution of flowering, a ratio of 261:77 was obtained; this ratio was consistent $(\mathrm{p}=0.50-0.30)$ with the expected $3: 1$ proportion for the segregation of alleles at a single locus. 
Segregation was bimodal for the 'BR 16 ' $\mathrm{x}$ BR92-14638 cross, with ratios of 246:21 and 227:20 in experiments I and II, respectively. These observed ratios were consistent with $(\mathrm{p}=0.30-0.20)$ the expected genotypic ratio of 15:1 for digenic segregation occurring in two loci. Late flowering in BR92-14638 is, therefore, controlled by two pairs of recessive alleles, acting additively to delay the onset of flowering by 25 days. Similarly, the $F_{2}$ plants of the E92-7 x BR92-14638 cross showed a bimodal distribution, resulting in observed ratios of 202:70 and 166:46 for experiments I and II, respectively. These proportions were consistent with the expected ratio of 3:1 for the segregation of a gene pair $(p=0.80-0.70$ and $p=0.30-0.20)$. Therefore, the difference in the days to flowering of the E92-7 and BR92-14638 variants is caused by the action of a main gene with complete dominance for early flowering. Genetic analysis of flowering time under short days revealed the existence of quantitative trait loci (QTLs) with additive expression, which govern flowering time and affect grain yield (Kong et al., 2010; Komatsu et al., 2011; Jung et al., 2012; Kim et al., 2012).

Given the agronomic-morphologic similarity and the distinct flowering of the three studied genotypes, it seems that natural mutations occurred in the BR 16 cultivar at two different loci. The BR 16 cultivar would, therefore, have a double dominant genotypic constitution $(A A B B)$ controlling early flowering. E92-7 differs from 'BR 16' by the presence of a pair of recessive alleles $(a a B B)$ responsible for delaying flowering by approximately ten days in early sowing. BR92-14638 is double recessive for both loci (aabb), and flowering in this variant occurs 25 and 15 days later than that of E92-7 and 'BR 16', respectively, for early sowing in October, in experiment I.

Earlier flowering in the Doko, BR 9 (Savana), Davis, Embrapa 1 (IAS 5RC), and BR 16 cultivars is controlled by genes that act in a completely dominant manner. In the studied crosses, no type of maternal inheritance controlled the early-flowering trait. Doko-18T and Doko-Milionária are identical mutants and differ genetically from the Doko cultivar by a pair of recessive genes that control the long juvenile period trait. The São Carlos variant differs from the Davis cultivar by a pair of recessive alleles that delay flowering by approximately 17 days under short-day conditions. It was not possible to establish the mode of action of the relevant gene in the E93-96 variant.
The E92-7 mutant differs from 'BR 16' by the presence of a pair of recessive genes. BR92-14638 has two mutant loci with two pairs of recessive genes that act additively.

\section{Conclusions}

1. The main component controlling the genetic variation of the long juvenile period trait in natural variants of soybean (Glycine max) is additive.

2. The difference in late flowering between 'Doko' and both of its variants was attributed to a recessive spontaneous mutation at the same genetic locus; however, Doko-18T and Doko-Milionária are identical mutants that share a pair of genes that control the long juvenile period under short-day conditions.

3. The mutants Doko-18T and Doko-Milionária can be used in breeding programs to develop cultivars adapted to low-latitude tropical regions.

\section{Acknowledgments}

To Coordenação de Aperfeiçoamento de Pessoal de Nível Superior (Capes), for financial support.

\section{References}

CARPENTIERI-PÍPOLO, V.; ALMEIDA, L.A. de; KIIHL, R.A. de $\mathrm{S}$. Inheritance of a long juvenile period under short-day conditions in soybean. Genetics and Molecular Biology, v.25, p.463-469, 2002. DOI: $10.1590 /$ S1415-47572002000400016.

CARPENTIERI-PÍPOLO, V.; ALMEIDA, L.A. de; KIIHL, R.A. de S.; ROSOLEM, C.A. Inheritance of long juvenile period under short day conditions for the BR80-6778 soybean (Glycine $\max ($ L.) Merrill) line. Euphytica, v.112, p.203-209, 2000. DOI: 101023/A:1003927817278.

COBER, E.R. Long juvenile soybean flowering responses under very short photoperiods. Crop Science, v.51, p.140-145, 2011. DOI: $10.2135 /$ cropsci2010.05.0262.

JUNG, C.-H.; WONG, C.E.; SINGH, M.B.; BHALLA, P.L. Comparative genomic analysis of soybean flowering genes. PLoS ONE, v.7, e38250, 2012. DOI: 10.1371/journal.pone.0038250.

KIM, M.Y.; SHIN, J.H.; KANG, Y.J.; SHIM, S.R.; LEE, S.H. Divergence of flowering genes in soybean. Journal of Biosciences, v.37, p.857-870, 2012. DOI: 10.1007/s12038-012-9252-0.

KOMATSU, K.; HWANG, T.-Y.; TAKAHASHI, M.; SAYAMA, T.; FUNATSUKI, H.; OKI, N.; ISHIMOTO, M. Identification of QTL controlling post-flowering period in soybean. Breeding Science, v.61, p.646-652, 2011. DOI: 10.1270/jsbbs.61.646.

KONG, F.; LIU, B.; XIA, Z.; SATO, S.; KIM, B.M.; WATANABE, S.; YAMADA, T.; TABATA, S.; KANAZAWA, A.; HARADA, K.; 
ABE, J. Two coordinately regulated homologs of FLOWERING LOCUS $\mathrm{T}$ are involved in the control of photoperiodic flowering in soybean. Plant Physiology, v.154, p.1220-1231, 2010. DOI: 10.1104/pp.110.160796.

LIU, B.; KANAZAWA, A.; MATSUMURA, H.; TAKAHASHI, R.; HARADA K.; ABE, J. Genetic redundancy in soybean photoresponses associated with duplication of the phytochrome A gene. Genetics, v.180, p.995-1007, 2008. DOI: 10.1534/ genetics.108.092742.

LIU, H.; WANG, H.; GAO, P.; XU, J.; XU, T.; WANG, J.; WANG, B.; LINC, C.; FU, Y.F. Analysis of clock gene homologs using unifoliolates as target organs in soybean (Glycine max). Journal of Plant Physiology, v.166, p.278-289, 2009. DOI: 10.1016/j. jplph.2008.06.003.
LIU, W.; KIM, M.Y.; KANG, Y.J.; VAN, K.; LEE, Y.H.; SRINIVES P.; YUAN, D.L.; LEE, S.-H. QTL identification of flowering time at three different latitudes reveals homeologous genomic regions that control flowering in soybean. Theoretical and Applied Genetics, v.123, p.545-553, 2011. DOI: 10.1007/ s00122-011-1606-8.

THAKARE, D.; KUMUDINI, S.; DINKINS, R.D. Expression of flowering-time genes in soybean E1 near-isogenic lines under short and long day conditions. Planta, v.231, p.951-963, 2010. DOI: 10.1007/s00425-010-1100-6.

WATANABE, S.; HARADA, K.; ABE, J. Genetic and molecular bases of photoperiod responses of flowering in soybean. Breeding Science, v.61, p.531-543, 2012. DOI: 10.1270/jsbbs.61.531.

Received on February 24, 2014 and accepted on September 15, 2014 